Session 2004-1840

\title{
TEACHING ENERGY SYSTEM DESIGN USING COMPUTER SIMULATION
}

\author{
Michael R. Sexton \\ Mechanical Engineering Department \\ Virginia Military Institute \\ Lexington, Virginia
}

\begin{abstract}
This paper describes the use of system simulation in teaching the design and optimization of energy systems at the undergraduate level. A case study involving the optimum design of a vapor compression refrigeration system is presented. This project was selected from senior level courses in Energy Conversion Design, Aircraft Propulsion and Internal Combustion Engines. The project selected is particularly relevant in that it demonstrates the use of several modeling and simulation techniques. The paper includes the project statement that provides the student with the design point operating characteristics, which are necessary to develop a design point thermodynamic model. Characteristic curves for the various system components used are also provided. The paper discusses the process by which the student must develop the system of equations necessary to model the thermal system and then use the model to predict the off-design performance of the system. The necessary equations to describe the various components and processes are developed from the first law of thermodynamics and appropriate heat transfer and power relationships. Additionally, curve fits of the graphic component characteristics data must be developed. The graphic data, representing components are curve fitted using multiple regression methods. For the case study project modeled, a system of seven linear/nonlinear equations is developed.
\end{abstract}

Mathcad was used for the simultaneous solution of the resulting system of equations. Although other software capable of solving this system of equations is available, Mathcad was selected because of the ease of programming and the capability to handle systems of nonlinear equations. The student can be given sufficient instruction to solve this system of equations with minimal class time taken away from the primary purpose of the courses, that is, the understanding and design of thermal systems. In the solution of any system involving nonlinear equations care must be taken in the selection of initial trial values of the unknown variables. For simulations close to the system's design operating point, the student simply chooses the design point values for initial trial values. For simulations that are further from the design operating conditions, the student must exercise some judgment in selecting these initial trial values. The student's understanding of the system's physical operation is necessary in the selection of these values. 
Symbols

$\mathrm{A}_{c} \quad$ Heat transfer area of condenser

$\mathrm{A}_{\mathrm{e}} \quad$ Heat transfer area of evaporator

$\mathrm{Cp}$ Constant pressure specific heat

$\mathrm{P} \quad$ Compressor power

$\mathrm{Q}_{\mathrm{c}} \quad$ Heat transfer from the condenser

$\mathrm{Q}_{\mathrm{e}} \quad$ Heat transfer to the evaporator

$\mathrm{T}_{\mathrm{c}} \quad$ Condenser temperature
$\mathrm{T}_{\mathrm{e}} \quad$ Evaporator temperature

$\mathrm{T}_{\mathrm{i}} \quad$ Inside air temperature

$\mathrm{T}_{\mathrm{o}} \quad$ Outside air temperature

U Overall heat transfer coefficient

$\mathrm{V}_{\text {inside }}$ Volume flow rate of inside air

$V_{\text {outside }}$ Volume flow rate of outside air

$\rho_{\text {in }} \quad$ Density of inside air

$\rho_{\text {out }} \quad$ Density of outside air

Introduction

This paper describes the use of system simulation in teaching the design and optimization of energy systems at the undergraduate level. The traditional approach to thermal systems design has been to define the system design point requirements. That is, for a particular energy system the design operating point requirements, such as, power for a thermal engine or cooling capacity for a refrigeration system, and performance factors, such as, efficiency or coefficient of performance would be specified. The system designer would then set about selecting hardware components that would work together in a system to accomplish the required task and meet performance requirements at the design operating point. Since all of the components were selected to operate at the design point the analysis to determine if the system would operate as specified was fairly straight forward. The off-design performance was often not examined do to the complexity of this analysis. As many energy systems are called upon to operate at off-design conditions during much of their operating life this design approach often led to significant performance shortcomings. Examples of these shortcomings would include the selection of a compressor and a turbine for a gas turbine engine that would meet operating performance at the specified design power condition but would have poor overall performance, low cycle efficiency, at part power load or when ambient conditions were different than those specified for design conditions. Or the selection of a condenser, evaporator, and compressor to achieve a desired cooling capacity and coefficient of performance (COP) for a vapor compression refrigeration system at a specified operating condition but would fall short of the required capacity and COP when ambient conditions changed. In this design process the decision to select a particular component for a system was frequently dictated by economic considerations. That is, will the more efficient component save sufficient money over the life of the system to justify the additional expense? If these economic design decisions were made without considering the offdesign performance a less than optimum design decision was likely to be made. The use of system simulation allows the off-design performance to be considered when these component design decisions are made.

In teaching the design of energy systems the use of system simulation allows the student to consider alternative equipment selections in the design process. The use of system simulation allows the system designer not only to achieve a workable system, but also, to obtain a system that is optimized based upon a specified design criterion. Many authors have discussed the concepts of workable and optimum designs. W. F. Stoecker in his text Design of Thermal System [1] first published 1971 discussed these ideas. Unfortunately, at that time the easy access to 
computers and user friendly software did not exist; therefore from a practical stand point only the simplest of energy systems could be analyzed by the student. With the development of computer hardware and user-friendly software the student can now handle much more complicated systems. This can be done without spending a disproportionate amount of class time and effort on the mathematics involved in the solution of systems of non-linear equations necessary to simulate energy systems. A number of suitable software packages are available. For the current work Mathcad was found to be a convenient and useful tool. Mathcad's format, which allows the equations to be entered in a form that resembles the mathematical expressions developed by the student, simplifies programming. Mathcad is also insensitive to the order in which the system of simultaneous equations is programmed. These Mathcad attributes allow the student to concentrate on the engineering involved in the project without being overwhelmed by the details of the mathematics required to solve the resulting system of nonlinear equations.

Mechanical engineering students at the Virginia Military Institute are exposed to the method of energy system design based on system simulation and optimization in several of the required and elective courses in the curriculum. These courses include a required course in Energy Conversion Design, and elective courses, such as, Internal Combustion Engines and Aircraft Propulsion. These energy systems design courses contain design projects that require the application of thermodynamics, fluid mechanics, and heat transfer in the design of energy conversion systems and system components using simulation and optimization in the design process. Several of these design simulations have been previously published. Sexton [2] described the simulation of a gas turbine engine that was used as a project for a senior energy conversion design course. Ngankeu, P.S.L., and Sexton, M.R. [3] describe the simulation of a hybrid solid oxide fuel cell that was developed as part of an undergraduate research project. Brandon, S.J., et al. [4] described the use of the simulation method in the actual design and construction of a gas turbine engine as a senior design project. Each of these projects required a relatively complex simulation of an energy system. The simplified gas turbine engine model required the simultaneous solution of a nonlinear system of 16 equations and the more complex model of the hybrid fuel cell system required the simultaneous solution of a non-linear system of 28 equations. A simple example of a class project assignment using simulation in the design of a refrigeration system is described below.

\section{Refrigeration System Design}

The problem statement (see below) provides the student with the design point operating specifications, including minimum cooling capacity, air temperatures and flow rates. The student is given performance curves, Figure 1, and costs for two available refrigeration compressors. The compressor characteristic curves were developed based upon commercially available hardware. For the case presented here a small compressor with a cost of $\$ 700$ and a large compressor with a cost of $\$ 800$ are considered. In addition, the student is provided with the surface area and overall heat transfer coefficients and costs for six evaporators, Table 2, and six condensers, Table 3 . The student must determine the combination of system components that provides a refrigeration system that will meet the minimum cooling requirements and provide the minimum life cycle cost while operating on a specified annual operating schedule. 


\section{Problem Statement}

As a design engineer, you have been asked to design a new vapor compression refrigeration system for your company. The new unit must meet the following specifications:

Minimum cooling capacity: $\quad 3.5$ tons

Entering inside air temperature: $\quad 75 \mathrm{~F}$

Indoor airflow: $2000 \mathrm{cfm}$

Entering outside air temperature: $\quad 95 \mathrm{~F}$

Outdoor airflow rate: $\quad 2500 \mathrm{cfm}$

You are asked to design a system that will minimize life cycle cost. The expected life of the system is 12 years (with no salvage value) and your company's cost of money is 5\%. The cost of electrical power is $0.1 \$ / \mathrm{kW}-\mathrm{hr}$. The system is estimated to operate on the annual operating schedule given in Table 1.

Table 1. ANNUAL OPERATING SCHEDULE

\begin{tabular}{|c|c|}
\hline Outdoor Temperature, $F$ & Cooling, ton-hrs \\
\hline 80 & 2023 \\
\hline 85 & 1491 \\
\hline 90 & 959 \\
\hline 95 & 318.5 \\
\hline 100 & 59.5 \\
\hline
\end{tabular}

Your design must be manufactured from the available "off-the-shelf" components. Specifications for available compressors, condensers, and evaporators are attached.

Provide the following information for your design:

Compressor model:

Evaporator model:

Condenser model:

Capacity (tons):

COP:

Evaporator temperature:

Condenser temperature:

Evaporator outlet temperature:

Condenser outlet temperature:

First cost:

Annual operating cost:

Present worth of investment:

Your design report should include: a summary cover letter, listings of the computer programs used (if applicable), an annotated set of hand calculations verifying the design selected, and a discussion of possible alternatives (i.e., are there other designs that may have worked and provide other features.)

With the information provided the student can develop the design point thermodynamic model necessary to describe the refrigeration system mathematically. The model is developed by modeling the performance of each component in the system using energy and mass balances along with the performance characteristics provided for each component. The required 
equations, including the first and second laws of thermodynamics necessary to describe the various components and processes and curve fits of the graphic component characteristics and working fluid property data, are developed. The graphic data representing the compressor is curve fitted using multiple regression methods. For this project the component models include the refrigeration compressor model, an evaporator model, and a condenser model. The development of these models is described in the following sections.
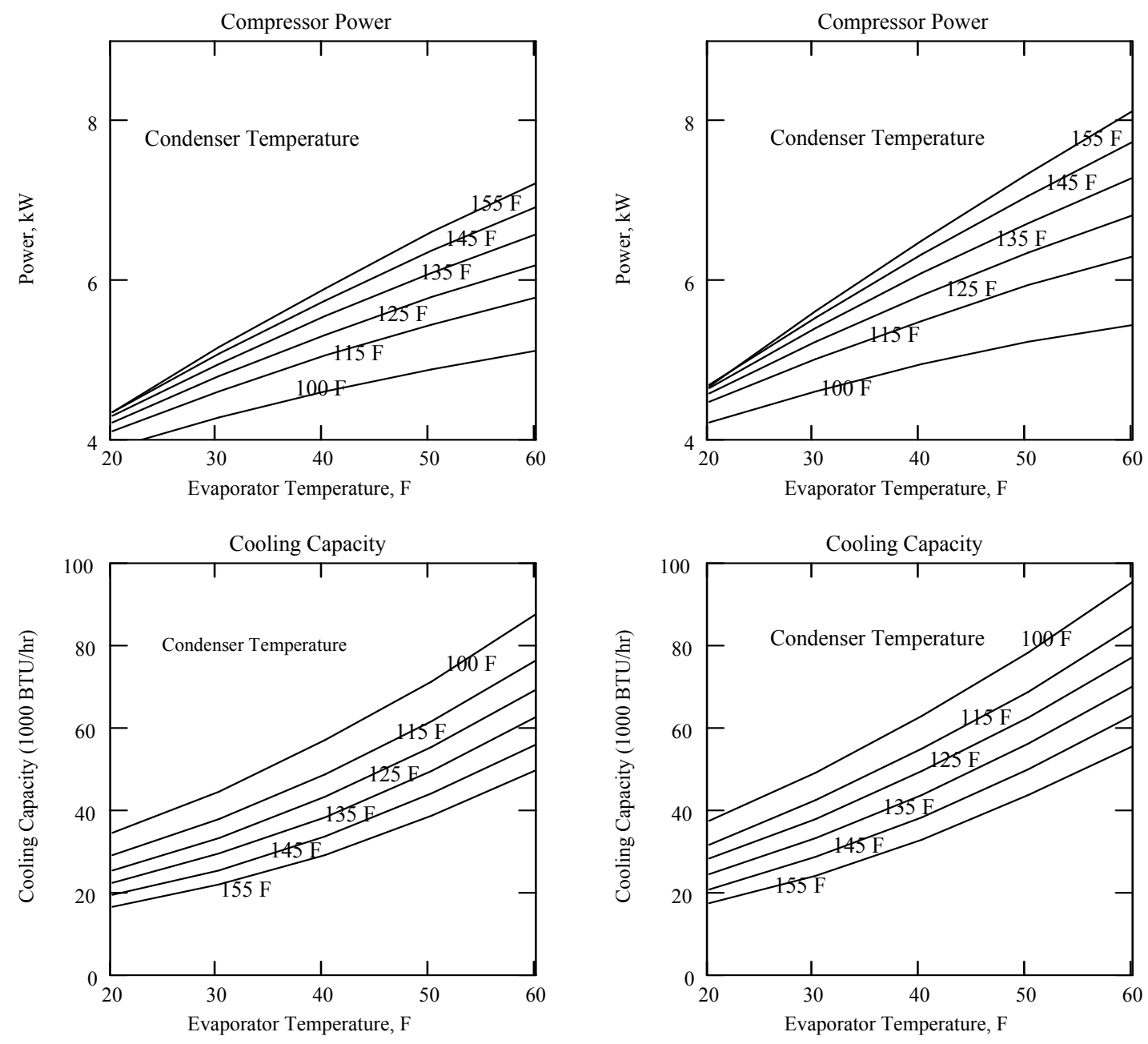

Small Compressor

Large Compressor

Figure 1. Refrigeration Capacity and Power Curves for Large and Small Compressors

\section{Compressor Model}

The graphic data (see Fig. 1) representing the available refrigeration compressors provides compressor power and cooling capacity, both as functions of evaporator and condenser temperatures. These operating characteristics are modeled by developing multiple regression curve fits for both the compressor power and cooling capacity. Equations (1) and (2) show the 
resulting second order polynomial equations that describe the compressor power and cooling capacity as functions of evaporator and condenser temperatures.

$$
\begin{gathered}
\mathrm{P}=\mathrm{Cp}_{0}+\mathrm{Cp}_{1} \mathrm{~T}_{\mathrm{e}}+\mathrm{Cp}_{2} \mathrm{~T}_{\mathrm{c}}+\mathrm{Cp}_{3} \mathrm{~T}_{\mathrm{e}}^{2}+\mathrm{Cp}_{4} \mathrm{~T}_{\mathrm{c}}^{2}+\mathrm{Cp}_{5} \mathrm{~T}_{\mathrm{e}} \mathrm{T}_{\mathrm{c}} \\
\mathrm{Q}_{\mathrm{e}}=\mathrm{Cq}_{0}+\mathrm{Cq}_{1} \mathrm{~T}_{\mathrm{e}}+\mathrm{Cq}_{2} \mathrm{~T}_{\mathrm{c}}+\mathrm{Cq}_{3} \mathrm{~T}_{\mathrm{e}}^{2}+\mathrm{Cq}_{4} \mathrm{~T}_{\mathrm{c}}^{2}+\mathrm{Cq}_{5} \mathrm{~T}_{\mathrm{e}} \mathrm{T}_{\mathrm{c}}
\end{gathered}
$$

The multiple regression curve fitting for this project was accomplished using FARNSFIT [4].

Table 2. EVAPORATOR DATA

\begin{tabular}{|l|l|l|}
\hline Model & UA (Btu/hr-F) & Cost $(\$)$ \\
\hline E1 & 1000 & 364 \\
\hline E2 & 1250 & 455 \\
\hline E3 & 1500 & 546 \\
\hline E4 & 1750 & 637 \\
\hline E5 & 2000 & 728 \\
\hline E6 & 2500 & 910 \\
\hline
\end{tabular}

Table 3. CONDENSER DATA

\begin{tabular}{|l|l|l|}
\hline \multicolumn{1}{|c|}{ Model } & UA (Btu/hr-F) & Cost (\$) \\
\hline C1 & 2000 & 394 \\
\hline C2 & 2500 & 492 \\
\hline C3 & 3000 & 591 \\
\hline C4 & 3500 & 690 \\
\hline C5 & 4000 & 788 \\
\hline C5 & 4500 & 886 \\
\hline
\end{tabular}

\section{Evaporator Model}

The evaporator is a heat exchanger that transfers heat from the inside air to the refrigerant, thereby cooling the air and evaporating the refrigerant. The evaporator is modeled using the given heat exchanger overall heat transfer coefficient, $U$, and the surface area, A, to calculate the heat transfer rate from the air to the refrigerant using the log mean temperature difference as defined in the heat transfer relationship given in Eqn. (3).

$$
\mathrm{Q}_{\mathrm{e}}=\mathrm{UA}_{\mathrm{e}} \cdot\left[\frac{\left(\mathrm{T}_{\mathrm{i} 1}-\mathrm{T}_{\mathrm{e}}\right)-\left(\mathrm{T}_{\mathrm{i} 2}-\mathrm{T}_{\mathrm{e}}\right)}{\ln \left(\frac{\mathrm{T}_{\mathrm{i} 1}-\mathrm{T}_{\mathrm{e}}}{\mathrm{T}_{\mathrm{i} 2}-\mathrm{T}_{\mathrm{e}}}\right)}\right]
$$


The heat transfer rate calculated in Eqn. (3) must match the heat transfer from the indoor air (cooling capacity) calculated using the energy balance (first law of thermodynamics) shown in Eqn. (4).

$$
\mathrm{Q}_{\mathrm{e}}=\rho_{\text {in }} \cdot \mathrm{V}_{\text {inside }} \cdot \mathrm{Cp} \cdot\left(\mathrm{T}_{\mathrm{i} 1}-\mathrm{T}_{\mathrm{i} 2}\right)
$$

This evaporator heat rate must also match the cooling capacity of the refrigerant compressor as defined in Eqn. (1).

\section{Condenser Model}

The condenser is modeled in a manner similar to the evaporator. The condenser is a heat exchanger that transfers heat from the refrigerant vapor in the condenser tubes, thereby cooling and condensing the refrigerant and heating up the outdoor air. The condenser is modeled by calculating the heat transfer rate to the air from the refrigerant using the heat exchanger overall heat transfer coefficient, $\mathrm{U}$, the surface area, A, and the log mean temperature difference as defined in the heat transfer relationship given in Eqn. (5).

$$
\mathrm{Q}_{\mathrm{c}}=\mathrm{UA}_{\mathrm{c}} \cdot\left[\frac{\left(\mathrm{T}_{\mathrm{c}}-\mathrm{T}_{\mathrm{o} 1}\right)-\left(\mathrm{T}_{\mathrm{c}}-\mathrm{T}_{\mathrm{o} 2}\right)}{\ln \left(\frac{\mathrm{T}_{\mathrm{c}}-\mathrm{T}_{\mathrm{o} 1}}{\mathrm{~T}_{\mathrm{c}}-\mathrm{T}_{\mathrm{o} 2}}\right)}\right]
$$

The heat transfer rate calculated in Eqn. (5) must match the heat transfer to the outdoor air calculated using the energy balance shown in Eqn. (6).

$$
\mathrm{Q}_{\mathrm{c}}=\rho_{\text {out }} \cdot \mathrm{V}_{\text {outside }} \cdot \mathrm{Cp} \cdot\left(\mathrm{T}_{\mathrm{o} 2}-\mathrm{T}_{\mathrm{o} 1}\right)
$$

\section{Energy Balance}

The final relationship necessary to complete the refrigeration model is an energy balance on the cycle. The first law of thermodynamics for a cycle states that the cyclic integral of the heats must equal the cyclic integral of the works; that is, the rate of heat transfer from the condenser must equal the sum of power into the compressor and the heat rate into the evaporator, as given by Eqn. (7).

$$
\mathrm{Q}_{\mathrm{c}}=\mathrm{Q}_{\mathrm{e}}+\mathrm{P}
$$

Solution of system of equations

The resulting system of equations involves seven linear/nonlinear equations and the seven unknown variables are the cooling capacity, $\mathrm{Q}_{\mathrm{e}}$, the condenser heat rate, $\mathrm{Q}_{\mathrm{c}}$, the compressor power, $\mathrm{P}$, the evaporator refrigerant temperature, $\mathrm{T}_{\mathrm{e}}$, the evaporator air outlet temperature, $\mathrm{T}_{\mathrm{i} 2}$, the condenser refrigerant temperature, $\mathrm{T}_{\mathrm{c}}$, and the condenser air outlet temperature, $\mathrm{T}_{\mathrm{o} 2}$. This system of equations must be solved simultaneously. For this problem the solution of the system of equations was accomplished using Mathcad 2001 Professional (a listing of the Mathcad 
program is shown in the appendix.) As with the solution of any system involving nonlinear equations (e.g., solving by Newton-Raphson) care must be taken in the selection of initial trial values of the unknown variables (evaporator temperature, condenser temperature, etc.). For operating points near the design operating point, these initial trial values are simply chosen to be the values at the design point. For operating points that are further from the design conditions the student must use some judgment in selecting these trial values. Physical understanding of the cycle's operation aids in the selection of these values. The student will observe the change in operating parameters as the system simulation is moved away from design conditions and then trial values can be selected.

After the simulation model for the refrigeration system has been developed the student can compare the performance of the system with various combinations of components (compressors, evaporators, and condensers.) Table 4 shows the results of the initial calculations to determine cooling capacity.

Table 4. Cooling Capacity (tons) for the combinations of compressor, evaporator, and condenser

\begin{tabular}{|c|c|c|c|c|c|c|}
\hline $\begin{array}{c}\text { Small } \\
\text { Compressor }\end{array}$ & E1 & E2 & E3 & E4 & E5 & E6 \\
\hline C1 & - & - & - & - & - & 3.524 \\
\hline C2 & - & - & - & - & - & 3.659 \\
\hline C3 & - & - & - & - & 3.577 & 3.748 \\
\hline C4 & - & - & - & 3.514 & 3.633 & 3.81 \\
\hline C5 & - & - & - & 3.552 & 3.673 & 3.855 \\
\hline C6 & - & - & - & 3.58 & 3.703 & 3.889 \\
\hline Large & E1 & E2 & E3 & E4 & E5 & E6 \\
Compressor. & & & & & & \\
\hline C1 & - & - & - & - & 3.556 & 3.713 \\
\hline C2 & - & - & - & 3.575 & 3.692 & 3.865 \\
\hline C3 & - & - & 3.501 & 3.656 & 3.78 & 3.964 \\
\hline C4 & - & - & 3.551 & 3.711 & 3.84 & 4.033 \\
\hline C5 & - & - & 3.586 & 3.751 & 3.884 & 4.082 \\
\hline C6 & - & - & 3.613 & 3.78 & 3.916 & 4.118 \\
\hline
\end{tabular}

Of the 72 possible design combinations 34 met the minimum specified cooling capacity of 3.5 tons and are included in the table. The equipment costs of the 34 designs that met the specified cooling requirement were then calculated and are shown in Table 5. The present worth investment of the 34 designs that met the specified cooling requirement was then calculated. This was accomplished by running a one-year operating simulation. From the annual energy usage for each design an annual operating cost was determined and a present worth of that cost was calculated. The results of those simulations are shown in Table 6 . 
Table 5. Equipment costs for the combinations of compressor, evaporator, and condenser that met the specified cooling requirement

\begin{tabular}{|c|c|c|c|c|c|c|}
\hline $\begin{array}{l}\text { Small } \\
\text { Compressor }\end{array}$ & E1 & E2 & E3 & E4 & E5 & E6 \\
\hline C1 & - & - & - & - & - & 2004 \\
\hline C2 & - & - & - & - & - & 2102 \\
\hline C3 & - & - & - & - & 2019 & 2201 \\
\hline C4 & - & - & - & 2027 & 2118 & 2300 \\
\hline C5 & - & - & - & 2125 & 2216 & 2398 \\
\hline C6 & - & - & - & 2223 & 2314 & 2496 \\
\hline $\begin{array}{l}\text { Large } \\
\text { Compressor }\end{array}$ & E1 & E2 & E3 & E4 & E5 & E6 \\
\hline C1 & - & - & - & - & 1922 & 2104 \\
\hline C2 & - & - & - & 1929 & 2020 & 2202 \\
\hline C3 & - & - & 1937 & 2028 & 2119 & 2301 \\
\hline C4 & - & - & 2036 & 2127 & 2218 & 2400 \\
\hline C5 & - & - & 2134 & 2225 & 2316 & 2498 \\
\hline C6 & - & - & 2232 & 2323 & 2414 & 2596 \\
\hline
\end{tabular}

Table 6. Present worth of investment for the combinations of compressor, evaporator, and condenser that met the specified cooling requirement

\begin{tabular}{|l|c|c|c|c|c|l|}
\hline $\begin{array}{l}\text { Small } \\
\text { Compressor }\end{array}$ & E1 & E2 & E3 & E4 & E5 & E6 \\
\hline C1 & - & - & - & - & - & 8501 \\
\hline C2 & - & - & - & - & - & 8152 \\
\hline C3 & - & - & - & - & 7886 & 7969 \\
\hline C4 & - & - & - & 7783 & 7802 & 7879 \\
\hline C5 & - & - & - & 7755 & 7769 & 7842 \\
\hline C6 & - & - & - & 7759 & 7771 & 7841 \\
\hline $\begin{array}{l}\text { Large } \\
\text { Compressor }\end{array}$ & E1 & E2 & E3 & E4 & E5 & E6 \\
\hline C1 & - & - & - & - & 8737 & 8869 \\
\hline C2 & - & - & - & 8316 & 8352 & 8461 \\
\hline C3 & - & - & 8121 & 8126 & 8153 & 8249 \\
\hline C4 & - & - & 8036 & 8032 & 8052 & 8139 \\
\hline C5 & - & - & 8004 & 7994 & 8010 & 8091 \\
\hline C6 & - & - & 8006 & 7992 & 8005 & 8081 \\
\hline
\end{tabular}

From inspection of Tables 5 and 6 it can be seen that the design that provides the minimum equipment cost is the large compressor with evaporator E5 and condenser C1 while the design that provides the minimum present worth investment, and therefore the design that meets the optimization criterion, is the small compressor with evaporator E4 and condenser $\mathrm{C} 5$. The results for the optimum design are then: 


$\begin{array}{ll}\text { Compressor model: } & \text { Small } \\ \text { Evaporator model: } & \mathrm{E} 4 \\ \text { Condenser model: } & \mathrm{C} 5 \\ \text { Capacity (tons): } & 3.552 \\ \text { COP: } & 2.37 \\ \text { Evaporator temperature: } & 39.3 \mathrm{~F} \\ \text { Condenser temperature: } & 124.9 \mathrm{~F} \\ \text { Evaporator outlet temperature: } 55 \mathrm{~F} \\ \text { Condenser outlet temperature: } & 118.5 \mathrm{~F} \\ \text { First cost: } & \$ 2125 \\ \text { Annual operating cost: } & \$ 635 \\ \text { Present worth of investment: } & \$ 7755\end{array}$

\section{Summary}

System simulation is a powerful tool for teaching the design of energy systems. It allows the student to consider alternative designs that only a few years ago would have required a prohibitive amount of time to analyze. It allows the student the option of selecting not only a workable system but also consider a system that is optimized to meet a specific optimization criterion. The use of a software tool like Mathcad allows the student to concentrate on the engineering principles involved in the project without being overwhelmed by the details of the mathematics involved in the solution of the resulting system of nonlinear equations.

Bibliography:

1. Stocker, W. F., Design of Thermal Systems, McGraw-Hill, New York, NY, 1971.

2. Sexton, M. R., "Gas Turbine Engine Simulation Using Mathcad: A Student Project," Proceedings of the ASEE Annual Conference (Charlotte, NC, June 1999.)

3. Ngankeu, P.S.L., and Sexton, M.R., "Simulation of a Hybrid Solid Oxide Fuel Cell Cycle: A Summer Undergraduate Research Project," Paper 2003-76, Proceedings of the ASEE Annual Conference (Nashville, June 2003.)

4. Brandon, S. J., Douglas J. W., and Sexton, M. R., "Gas Turbine Engine: A Senior Design Project," Proceedings of the ASEE Annual Conference (St Louis, MO, June 2000.)

5. Farnsworth, D. A., "FARNSFIT -Curve Fitting and Plotting," Lynchburg, VA, 1986.

MICHAEL R. SEXTON

Michael R. Sexton is a Professor of Mechanical Engineering at the Virginia Military Institute. His current research and teaching interests include turbomachinery and energy system design and optimization. Dr. Sexton holds B.S., M.S., and Ph.D. degrees in Mechanical Engineering from Virginia Tech.

Proceedings of the 2004 American Society for Engineering

Education Annual Conference \& Exposition

Copyright $($ ) 2004, American Society for Engineering Education 


\section{APPENDIX \\ MATHCAD SOLUTION FOR \\ REFRIGERATION SYSTEM \\ PERFORMANCE \\ Specified design air temperature}

Specified air flow rates

$\mathrm{V}_{\text {inside }}:=2000 \frac{\mathrm{ft}^{3}}{\min } \quad \mathrm{V}_{\text {outside }}:=2500 \frac{\mathrm{ft}^{3}}{\mathrm{~min}}$

$\mathrm{T}_{\mathrm{i} 1}:=75 \cdot \mathrm{F} \quad \mathrm{T}_{\mathrm{o} 1}:=95 \cdot \mathrm{F}$

Specified Power Cost

Present Worth Factor

12 year life $5 \%$ interest rate

Cost power $:=0.1 \cdot \frac{1}{\mathrm{~kW} \cdot \mathrm{hr}}$

$\mathrm{PWF}:=8.863$

Specifif heat for air

$\mathrm{Cp}:=0.24 \frac{\mathrm{BTU}}{\mathrm{lb} \cdot \mathrm{F}}$

Calculated air densities for 1 atmosphere and specified air temperatures

$$
\rho_{\text {in }}:=\frac{14.7 \cdot \frac{\mathrm{lbf}}{\mathrm{in}^{2}}}{53.35 \cdot \frac{\mathrm{lbf} \cdot \mathrm{ft}}{\mathrm{lb} \cdot \mathrm{R}} \cdot\left(\mathrm{T}_{\mathrm{i} 1} \cdot \frac{1}{\mathrm{~F}}+460\right) \cdot \mathrm{R}} \quad \rho_{\text {out }}:=\frac{14.7 \cdot \frac{\mathrm{lbf}}{\mathrm{in}^{2}}}{53.35 \cdot \frac{\mathrm{lbf} \cdot \mathrm{ft}}{\mathrm{lb} \cdot \mathrm{R}} \cdot\left(\mathrm{T}_{\mathrm{o} 1} \cdot \frac{1}{\mathrm{~F}}+460\right) \cdot \mathrm{R}}
$$

Selected Compressor, Evaporator, and Condenser to be modeled

Evaporator E4

$$
\mathrm{UA}_{\mathrm{e}}:=1750 \frac{\mathrm{BTU}}{\mathrm{hr} \cdot \mathrm{F}} \quad \operatorname{CostUA}_{\mathrm{e}}:=637
$$

Condenser C5

$\mathrm{UA}_{\mathrm{c}}:=4000 \frac{\mathrm{BTU}}{\mathrm{hr} \cdot \mathrm{F}} \quad \operatorname{CostUA} \mathrm{c}:=78 \varepsilon$

Selected Starting Values for Evaporator and Condenser Temperatures

$\mathrm{T}_{\mathrm{c}}:=125 \mathrm{~F} \quad \mathrm{~T}_{\mathrm{e}}:=45 \mathrm{~F}$

Calculate remaining starting values for unknown variables based on starting values ofEvaporator and Condenser Temperatures

$$
\begin{aligned}
& \mathrm{P}:=\left(\mathrm{Cp}_{0}+\mathrm{Cp}_{1} \cdot \mathrm{T}_{\mathrm{e}} \cdot \frac{1}{\mathrm{~F}}+\mathrm{Cp}_{2} \cdot \mathrm{T}_{\mathrm{c}} \cdot \frac{1}{\mathrm{~F}}+\mathrm{Cp}_{3} \cdot \mathrm{T}_{\mathrm{e}}^{2} \cdot \frac{1}{\mathrm{~F}^{2}}+\mathrm{Cp}_{4} \cdot \mathrm{T}_{\mathrm{c}}^{2} \cdot \frac{1}{\mathrm{~F}^{2}}+\mathrm{Cp}_{5} \cdot \mathrm{T}_{\mathrm{c}} \cdot \mathrm{T}_{\mathrm{e}} \cdot \frac{1}{\mathrm{~F}^{2}}\right) 3412 \cdot \frac{\mathrm{BTU}}{\mathrm{hr}} \\
& \mathrm{P}=1.893 \times 10 \frac{\mathrm{BTU}}{\mathrm{hr}} \\
& \mathrm{Q}_{\mathrm{e}}:=\left(\mathrm{Cq}_{0}+\mathrm{Cq}_{1} \cdot \mathrm{T}_{\mathrm{e}} \cdot \frac{1}{\mathrm{~F}}+\mathrm{Cq}_{2} \cdot \mathrm{T}_{\mathrm{c}} \cdot \frac{1}{\mathrm{~F}}+\mathrm{Cq}_{3} \cdot \mathrm{T}_{\mathrm{e}}^{2} \cdot \frac{1}{\mathrm{~F}^{2}}+\mathrm{Cq}_{4} \cdot \mathrm{T}_{\mathrm{c}}^{2} \cdot \frac{1}{\mathrm{~F}^{2}}+\mathrm{Cq}_{5} \cdot \mathrm{T}_{\mathrm{c}} \cdot \mathrm{T}_{\mathrm{e}} \cdot \frac{1}{\mathrm{~F}^{2}}\right) \cdot 1000 \frac{\mathrm{BTU}}{\mathrm{hr}} \\
& \mathrm{Q}_{\mathrm{e}}=4.907 \times 10^{4} \frac{\mathrm{BTU}}{\mathrm{hr}} \quad \mathrm{T}_{\mathrm{i} 2}:=\mathrm{T}_{\mathrm{i} 1}-\frac{\mathrm{Q}_{\mathrm{e}}}{\left(\rho_{\text {in }} \cdot \mathrm{V}_{\text {inside }} \cdot \mathrm{Cp}\right)} \quad \mathrm{T}_{\mathrm{O} 2}:=\mathrm{T}_{\mathrm{o} 1}+\frac{\mathrm{Q}_{\mathrm{c}}}{\left(\rho_{\text {out }} \cdot \mathrm{V}_{\mathrm{outside}} \cdot \mathrm{Cp}\right)} \\
& \mathrm{Q}_{\mathrm{c}}:=\mathrm{Q}_{\mathrm{e}}+\mathrm{P} \quad \mathrm{T}_{\mathrm{i} 2}=52.025 \mathrm{~F} \quad \mathrm{~T}_{\mathrm{o} 2}=121.423 \mathrm{~F}
\end{aligned}
$$

Proceedings of the 2004 American Society for Engineering 
System of simultaneous equations to be solved

Given

$$
\begin{aligned}
& \mathrm{P}=\left(\mathrm{Cp}_{0}+\mathrm{Cp}_{1} \cdot \mathrm{T}_{\mathrm{e}} \cdot \frac{1}{\mathrm{~F}}+\mathrm{Cp}_{2} \cdot \mathrm{T}_{\mathrm{c}} \cdot \frac{1}{\mathrm{~F}}+\mathrm{Cp}_{3} \cdot \mathrm{T}_{\mathrm{e}}^{2} \cdot \frac{1}{\mathrm{~F}^{2}}+\mathrm{Cp}_{4} \cdot \mathrm{T}_{\mathrm{c}}{ }^{2} \cdot \frac{1}{\mathrm{~F}^{2}}+\mathrm{Cp}_{5} \cdot \mathrm{T}_{\mathrm{c}} \cdot \mathrm{T}_{\mathrm{e}} \cdot \frac{1}{\mathrm{~F}^{2}}\right) 3412 \cdot \frac{\mathrm{BTU}}{\mathrm{hr}} \\
& \mathrm{Q}_{\mathrm{e}}=\left(\mathrm{Cq}_{0}+\mathrm{Cq}_{1} \cdot \mathrm{T}_{\mathrm{e}} \cdot \frac{1}{\mathrm{~F}}+\mathrm{Cq}_{2} \cdot \mathrm{T}_{\mathrm{c}} \cdot \frac{1}{\mathrm{~F}}+\mathrm{Cq}_{3} \cdot \mathrm{T}_{\mathrm{e}}{ }^{2} \cdot \frac{1}{\mathrm{~F}^{2}}+\mathrm{Cq}_{4} \cdot \mathrm{T}_{\mathrm{c}}{ }^{2} \cdot \frac{1}{\mathrm{~F}^{2}}+\mathrm{Cq}_{5} \cdot \mathrm{T}_{\mathrm{c}} \cdot \mathrm{T}_{\mathrm{e}} \cdot \frac{1}{\mathrm{~F}^{2}}\right) \cdot 1000 \frac{\mathrm{BTU}}{\mathrm{hr}} \\
& \mathrm{Q}_{\mathrm{e}}=\mathrm{UA}_{\mathrm{e}} \cdot\left[\frac{\left(\mathrm{T}_{\mathrm{i} 1}-\mathrm{T}_{\mathrm{e}}\right)-\left(\mathrm{T}_{\mathrm{i} 2}-\mathrm{T}_{\mathrm{e}}\right)}{\ln \left(\frac{\mathrm{T}_{\mathrm{i} 1}-\mathrm{T}_{\mathrm{e}}}{\mathrm{T}_{\mathrm{i} 2}-\mathrm{T}_{\mathrm{e}}}\right)}\right] \\
& \mathrm{Q}_{\mathrm{c}}=\mathrm{UA}_{\mathrm{c}} \cdot\left[\frac{\left(\mathrm{T}_{\mathrm{c}}-\mathrm{T}_{\mathrm{o} 1}\right)-\left(\mathrm{T}_{\mathrm{c}}-\mathrm{T}_{\mathrm{o} 2}\right)}{\ln \left(\frac{\mathrm{T}_{\mathrm{c}}-\mathrm{T}_{\mathrm{o} 1}}{\mathrm{~T}_{\mathrm{c}}-\mathrm{T}_{\mathrm{o} 2}}\right)}\right] \\
& \mathrm{Q}_{\mathrm{e}}=\rho_{\text {in }} \cdot \mathrm{V}_{\text {inside }} \cdot \mathrm{Cp} \cdot\left(\mathrm{T}_{\mathrm{i} 1}-\mathrm{T}_{\mathrm{i} 2}\right) \\
& \mathrm{Q}_{\mathrm{c}}=\rho_{\text {out }} \cdot \mathrm{V}_{\text {outside }} \cdot \mathrm{Cp} \cdot\left(\mathrm{T}_{\mathrm{o} 2}-\mathrm{T}_{\mathrm{o} 1}\right) \\
& \mathrm{Q}_{\mathrm{c}}=\mathrm{Q}_{\mathrm{e}}+\mathrm{P} \quad \text { (7) }
\end{aligned}
$$

Solution of Equations

$$
\begin{aligned}
& \left(\begin{array}{c}
\mathrm{Q}_{\mathrm{e}} \\
\mathrm{Q}_{\mathrm{c}} \\
\mathrm{P} \\
\mathrm{T}_{\mathrm{i} 2} \\
\mathrm{~T}_{\mathrm{o} 2} \\
\mathrm{~T}_{\mathrm{e}} \\
\mathrm{T}_{\mathrm{c}}
\end{array}\right):=\operatorname{Find}\left(\mathrm{Q}_{\mathrm{e}}, \mathrm{Q}_{\mathrm{c}}, \mathrm{P}, \mathrm{T}_{\mathrm{i} 2}, \mathrm{~T}_{\mathrm{o} 2}, \mathrm{~T}_{\mathrm{e}}, \mathrm{T}_{\mathrm{c}}\right) \\
& \mathrm{Q}_{\mathrm{e}}=4.262 \times 10^{4} \frac{\mathrm{BTU}}{\mathrm{hr}} \quad \mathrm{T}_{\mathrm{i} 2}=55.046 \mathrm{~F} \quad \mathrm{~T}_{\mathrm{e}}=39.321 \mathrm{~F} \\
& \mathrm{Q}_{\mathrm{c}}=6.061 \times 10^{4} \frac{\mathrm{BTU}}{\mathrm{hr}} \quad \mathrm{T}_{\mathrm{o} 2}=118.549 \mathrm{~F} \quad \mathrm{~T}_{\mathrm{c}}=124.86 \mathrm{~F} \\
& \mathrm{P}=5.271 \times 10^{3} \mathrm{~W} \\
& \mathrm{Q}_{\text {tons }}:=\frac{\mathrm{Q}_{\mathrm{e}}}{12000 \frac{\mathrm{BTU}}{\mathrm{hr}}} \quad \text { COP }:=\frac{\mathrm{Q}_{\mathrm{e}}}{\mathrm{P}} \\
& \mathrm{Q}_{\text {tons }}=3.552 \quad \mathrm{COP}=2.37
\end{aligned}
$$

Proceedings of the 2004 American Society for Engineering Education Annual Conference \& Exposition Copyright (C) 2004, American Society for Engineering Education 